\title{
PROSPECTION OF FILAMENTOUS FUNGI AND THE PRODUCTION OF AMYLASE BY ASPERGILLUS sp. M1.7.2
}

\section{PROSPECÇÃO DE FUNGOS FILAMENTOSOS E PRODUÇÃO DE AMILASES POR ASPERGILLUS sp. M1.7.2}

\author{
M. T. S. SOUZA ${ }^{1}$, B. M. MARINHO ${ }^{2}$, T. M. PASIN ${ }^{3}$, D. L. NELSON $^{4}$ e V. M. BENASSI ${ }^{5^{*}}$
}

${ }^{1}$ Universidade Federal dos Vales do Jequitinhonha e Mucuri (UFVJM) campus Janaúba, Instituto de Engenharia, Ciência e Tecnologia, Janaúba, MG, Brazil.

${ }^{2}$ Universidade Estadual de Montes Claros, Departamento de Medicina, Montes Claros, MG, Brazil.

${ }^{3}$ Universidade de São Paulo (USP) campus Ribeirão Preto, Faculdade de Medicina de Ribeirão Preto, Departamento de Bioquímica e Imunologia, Ribeirão Preto, SP, Brazil.

${ }^{4}$ Universidade Federal dos Vales do Jequitinhonha e Mucuri (UFVJM) campus JK, Professor Visitante do Programa de Pós-Graduação em Biocombustíveis, Diamantina, MG, Brazil.

${ }^{5}$ Universidade Federal dos Vales do Jequitinhonha e Mucuri (UFVJM) campus JK, Instituto de Ciência e Tecnologia, Diamantina, MG, Brazil.

${ }^{*}$ Corresponding author: Instituto de Ciência e Tecnologia, Universidade Federal dos Vales do Jequitinhonha e Mucuri, Diamantina, MG, Brasil, Fone: +55 38 99957-9787

Endereço de E-mail: vivian.benassi@ufvjm.edu.br(V.M.Benassi).

\begin{tabular}{|c|}
\hline A R T I C L E I N F O \\
\hline $\begin{array}{l}\text { Article history: } \\
\text { Received 2020-06-17 } \\
\text { Accepted 2020-09-04 } \\
\text { Available online 2020-09-04 }\end{array}$ \\
\hline $\begin{array}{l}\text { palavras-chave } \\
\text { Enzimas } \\
\text { Fungos Filamentosos } \\
\text { Bioprospecção } \\
\text { Biotecnologia }\end{array}$ \\
\hline $\begin{array}{l}\frac{k e y w o r d s}{\text { Enzymes }} \\
\text { Filamentous fungi } \\
\text { Bioprospecting } \\
\text { Biotechnology }\end{array}$ \\
\hline
\end{tabular}

\begin{abstract}
A B S T R A C T
Amylases are used in numerous industrial applications for converting starch into products of greater value. This work aimed to prospect filamentous fungi, analyze the morphological and physiological characteristics of the isolates; as well as to select an amylase producing fungus and to optimize the parameters for the cultivation of the microorganism and biochemically characterize the amylase. Among 21 filamentous fungi isolated in Janaúba, state of Minas Gerais, Brazil, the best amylase producer was selected for standardization of culture parameters and subsequent enzymatic characterization. Maximum activity was obtained in $C P$ medium after six days of cultivation at $30^{\circ} \mathrm{C}$. Amylases produced by this fungus are stable to variations in $\mathrm{pH}$ and temperature, exhibited optimum activities at $65^{\circ} \mathrm{C}$ and $\mathrm{pH}$ 6.0, and were significantly activated in the presence of 5 and $10 \mathrm{~mm} \mathrm{KH}_{2} \mathrm{PO}_{4}$.
\end{abstract}

\section{R E S UM O}

As amilases são utilizadas em inúmeras aplicações industriais para a conversão de amido em produtos de maior valor agregado. Esse trabalho objetivou prospectar fungos filamentosos, analisar as características morfológicas e fisiológicas dos isolados, assim como, selecionar fungo produtor de amilases e otimizar os parâmetros de cultivo do microrganismo e caracterizar bioquimicamente a amilase. Dos vinte e um fungos filamentosos isolados em Janaúba, Minas Gerais, Brasil, foi selecionado o melhor produtor de amilases para padronização dos parâmetros de cultivo e posterior caracterização enzimática. A máxima atividade foi obtida em meio $C P$, após seis dias de cultivo, a $30{ }^{\circ} \mathrm{C}$. As amilases produzidas são estáveis ao $\mathrm{pH}$ e à temperatura; apresentaram maiores atividades a $65^{\circ} \mathrm{C} \mathrm{em} \mathrm{pH}$ 6,0 sendo significativamente ativadas na presença de 5 e $10 \mathrm{mM}$ de $\mathrm{KH}_{2} \mathrm{PO}_{4}$. 


\section{INTRODUCTION}

Enzymes are biological catalysts used in the most diverse industrial sectors because they are capable of producing compounds of high value in an efficient, economical and sustainable manner (Oliveira et al., 2004; Mussatto et al., 2007; Pasin et al., 2014; Pasin et al., 2019). The enzymes occur naturally in all living beings, from the simplest to the most evolved organism, because the biological catalysts are indispensable to metabolism (Leadley, 1993; Oliveira, 2014; Rosado, 2013).

In industry, enzymes of microbial origin have stood out because microbes have a potential for production and secretion of a diversity of these catalysts (Benassi, 2012). Bacteria, yeasts and filamentous fungi have become the current focus of research for enzymes with a potential for industrial applications. Currently, the global market for industrial enzymes is well established; according to the study published by BCC Research (2017), it is estimated that the market value might reach US\$ 6.3 billion in 2021 .

Enzymes are separated into six classes according to the type of reaction they catalyze: transferases, lyases, isomerases, oxidoreductases, ligases and hydrolases. Approximately $80 \%$ of the enzymes used in industry correspond to hydrolases. Of this class, proteases and amylases lead the world production on an industrial scale (Nguyen et al., 2002; Coelho, 2008; Benassi, 2012; Rosado, 2013). The application of amylases is widespread in the most diverse industries and processes (Pandey et al., 2005; Wanderley et al., 2011; Lima et al., 2015), such as in starch saccharification, in textile, food and animal feed industries, in detergents, and in fermented drinks and distilleries. They also have a potential for application in the pharmaceutical and refined chemical industries (Benassi, 2012; Pandey et al., 2015), where they replace semi-integrally the chemical hydrolysis of starch.

Despite the variety and quantity of renewable raw materials and the knowledge for producing enzymes with largescale biotechnological potential, enzyme technology is visibly lagging behind in Brazil. Studies reveal that Brazil imports most products that involve enzyme preparations, thereby demonstrating the fragility of our enzyme market in relation to global demand (Politzer et al., 2006, Pasin et al., 2014). Thus, the prospecting of microorganisms, the analysis and the optimization of the production of industrially important enzymes, such as amylases, are of paramount importance for the development of this sector in the country.

Enzymes with high catalytic activity at lower temperatures would generate energy savings in industrial processes (Carrasco, et al., 2017), and they are being widely searched. Thermostable enzymes, which can be applied to processes that must necessarily occur at elevated temperatures, and especially, enzymes that are stable at the various $\mathrm{pHs}$ utilized in industrial processes are being sought (Rabelo, 20017; Pasin et al., 2017).
This work sought to prospect filamentous fungi isolated from different samples collected in the city of Janaúba, in the north of the state of Minas Gerais, Brazil; to analyze the morphological and physiological characteristics of the isolates; to select an amylase-producing fungus; to optimize the physical-chemical parameters for the cultivation of the microorganism to improve the production of the enzyme; and, finally, to biochemically characterize the amylase produced by determining the optimum conditions for the enzymatic reaction, thermal and $\mathrm{pH}$ stability and analysis of the effect of adding ions to the reaction medium.

\section{MATERIAL AND METHODS}

\subsection{Sampling, Isolation and Identification of Possible Fungus Genus}

The sampling of the material for isolation of the microorganisms was performed in the city of Janaúba, located in the north of the state of Minas Gerais, $15^{\circ} 48^{\prime} 09^{\prime \prime} \mathrm{S}$ e $43^{\circ} 18^{\prime} 32^{\prime \prime}$ $\mathrm{W}$. The material was collected aseptically. The three samples were collected: trunk bark (1), fruit skins (2) and decomposing foliage of Licania tomentosa (3). The samples were stored in glass flasks stoppered with hydrophobic cotton. The flasks were previously autoclaved at $120{ }^{\circ} \mathrm{C}$ and $1.5 \mathrm{~atm}$ during 30 minutes.

The materials were transported aseptically to the Biology Laboratory of the Institute of Engineering, Science and Technology of the Janaúba campus of the Universidade Federal dos Vales do Jequitinhonha e Mucuri (UFVJM). Each sample was placed in a Petri dish containing from 15 to $20 \mathrm{~mL}$ of Emerson sterile culture medium (1941) with the aid of an autoclaved forceps to allow the microorganisms present in the samples to develop. Subsequently, the plates containing the material were placed in a bacteriological oven at $30{ }^{\circ} \mathrm{C}$ for four days. The growth of new microorganisms was analyzed every 24 hours. As the specimens grew, point isolation was performed in the center of a new culture plate containing the same medium and maintained at $30{ }^{\circ} \mathrm{C}$

The isolation was accomplished according to the observation of important characteristics of the fungal somatic and reproductive structures, such as colony colors, pigmentation and texture (Domsch et al., 2007). The microculture was performed to identify the strains obtained at the genus level (Lacaz et al., 1991). The analysis of macroscopic characteristics, such as the conidiophore facilitated further identification of fungi, as previously described by Pasin et al. (2019).

The analysis of the growth of fungi with respect to temperature was performed for 48 hours in a Potato-DextroseAgar (BDA) culture medium from $35^{\circ} \mathrm{C}$ to $50^{\circ} \mathrm{C}$, with intervals of $5^{\circ} \mathrm{C}$. The growth halo was measured, and the fungal growth rate in centimeter per hour $(\mathrm{mm} / \mathrm{h})$ was calculated. The strains were maintained in solid Emerson medium (1941) in inclined test tubes. Transplants were performed periodically, kept at 30 ${ }^{\circ} \mathrm{C}$ in a bacteriological oven for seven days and, subsequently, stored at $4{ }^{\circ} \mathrm{C}$. The fungus samples were also kept at $4{ }^{\circ} \mathrm{C}$ on silica gel, according to the method of Michelin (2009). 


\subsection{Selection of Potential Amylase-Producing Fungi}

The analysis of potential amylolytic fungi was qualitatively performed with all the fungi isolated by cultivating them in a solid medium BDA at $35^{\circ} \mathrm{C}$. The halo of enzymatic degradation was revealed through the addition of a Lugol solution.

Four of the best enzyme producers were grown in $\mathrm{CP}$ submerged culture medium (Peixoto et al., 2003) at pH 6.5, using Dinâmica ${ }^{\circledR}$ soluble starch as a carbon source at a concentration of 1.5 and the inoculum was standardized at 1.1 $\mathrm{x} 10^{7}$ spores. The medium was previously autoclaved and incubated at $30{ }^{\circ} \mathrm{C}$ in a bacteriological oven without stirring for three days. The media were vacuum filtered, and the crude enzyme extract obtained was used to quantify the amylolytic activity using the same conditions under which they were grown.

\subsection{Fungus Inoculum in Culture Medium}

The inoculum process consisted of scraping the fungus maintenance tubes and diluting the spores in approximately 10 $\mathrm{mL}$ of sterile distilled water, and then transferring one milliliter of this suspension, $1.1 \times 10^{7}$ spores, to a $125 \mathrm{~mL}$ Erlenmeyer flask containing $25 \mathrm{~mL}$ of the submerged medium.

\subsection{Obtaining Mycelial Mass and Enzyme Extract}

The mycelial mass was obtained through vacuum filtration through a Büchner funnel containing $12.5 \mathrm{~cm}$ diameter Unifil ${ }^{\circledR}$ filter paper. After drying, at room temperature, the mycelial mass was weighed on an analytical balance. The filtrates containing the extracellular enzymes were subjected to measurement of $\mathrm{pH}$, volume and determination of the amylolytic activity.

\subsection{Dosage of Amylolytic Activity}

Amylolytic activity was determined by quantifying the reducing sugars formed during the enzymatic reaction using 3',5'-dinitrosalicylic acid (DNS), as suggested by Miller (1959). The enzyme-catalyzed reaction consisted of the incubation of $1000 \varepsilon \mathrm{L}$ of the $1 \%(\mathrm{w} / \mathrm{v})$ starch substrate in $100 \mathrm{mM}$ sodium acetate buffer, $\mathrm{pH} 5.0$, together with $1000 \varepsilon \mathrm{L}$ of the crude extracellular extract, in a water bath at $55^{\circ} \mathrm{C}$ for 5 minutes. After the reaction, aliquots of $400 \varepsilon \mathrm{L}$ were removed and added to tubes containing $400 \varepsilon \mathrm{L}$ of DNS. A $400 \varepsilon \mathrm{L}$ aliquot was removed from the reaction mixture immediately after adding the enzyme extract to the substrate. This aliquot was transferred to a tube containing $400 \varepsilon \mathrm{L}$ of DNS reagent, and this sample was used to control the reaction (zero time). Subsequently, the tubes were boiled for 5 minutes and, after cooling, $4000 \varepsilon \mathrm{L}$ of distilled water was added. Readings were taken at $540 \mathrm{~nm}$ in a Femto ${ }^{\circledR}$ spectrophotometer and compared with that corresponding to the reaction time zero.

The method was previously standardized using glucose $(0.1$ i $1.0 \mathrm{mg} / \mathrm{mL})$. The unit of activity (U) was defined as the amount of enzyme that hydrolyzes one $\varepsilon$ mol of soluble starch per minute under the test conditions. Total activity (total $\mathrm{U})=$ $\varepsilon \mathrm{mol} / \mathrm{mL} \mathrm{x}$ volume of filtrate.

2.6 Definition of the Culture Medium for the Fungus Cultivation and Production of Amylases
The original culture media used in this work should be composed as follows: Khanna medium - $5 \mathrm{~mL}$ of mineral solution 20-fold concentrated, constituted $(\mathrm{g} / 100 \mathrm{~mL})$ of 2 $\mathrm{NH}_{4} \mathrm{NO}_{3}, 1.3 \mathrm{KH}_{2} \mathrm{PO}_{4}, 0.362 \mathrm{MgSO}_{4} .7 \mathrm{H}_{2} \mathrm{O}, 0.098 \mathrm{KCl}, 0.007$ $\mathrm{ZnSO}_{4} \cdot \mathrm{H}_{2} \mathrm{O}, 0.0138 \mathrm{MnSO}_{4} \cdot \mathrm{H}_{2} \mathrm{O}, 0.0066 \mathrm{FeCl}_{3} .6 \mathrm{H}_{2} \mathrm{O}, 0.0062$ $\mathrm{CuSO}_{4} .5 \mathrm{H}_{2} \mathrm{O}$ and 0.1 yeast extract (Khanna et al., 1995); SR medium - $5 \mathrm{~mL}$ of mineral solution 50-fold concentrated, constituted $(\mathrm{g} / 100 \mathrm{~mL})$ of $0.3 \mathrm{KH}_{2} \mathrm{PO}_{4}, 0.23 \mathrm{MgSO}_{4} .7 \mathrm{H}_{2} \mathrm{O}$ and $1 \mathrm{NH}_{4} \mathrm{H}_{2} \mathrm{PO}_{4}, 0.02$ yeast extract and 0.45 peptone (Rizzatti et al., 2001); Czapek medium - (g/100 mL) $0.3 \mathrm{NaNO}_{3}, 0.1$ $\mathrm{KH}_{2} \mathrm{PO}_{4}, 0.5 \mathrm{MgSO}_{4} .7 \mathrm{H}_{2} \mathrm{O}, 0.5 \mathrm{KCl}, 0.001 \quad \mathrm{FeSO}_{4} .7 \mathrm{H}_{2} \mathrm{O}$ (Wiseman, 1975) and CP medium - $(\mathrm{g} / 100 \mathrm{~mL}) 0.03 \mathrm{KH}_{2} \mathrm{PO}_{4}$, $0.05 \mathrm{MgSO}_{4} .7 \mathrm{H}_{2} \mathrm{O}$ and 0.8 yeast extract (Peixoto et al., 2003).

Different culture media were tested to select a favorable medium for the production of amylases by Aspergillus sp. M1.7.2. The media tested were Khanna (Khanna et al., 1995) modified by the removal of the $\mathrm{NH}_{4} \mathrm{NO}_{3}, \mathrm{KCl}, \mathrm{ZnSO}_{4}, \mathrm{MnSO}_{4}$, and $\mathrm{FeCl}_{3}$ salts and the addition of $\mathrm{ZnCl}_{2}$ and $\mathrm{ZnCl}_{3}$; SR (Rizzatti et al., 2001) modified by removing $\mathrm{NH}_{4} \mathrm{H}_{2} \mathrm{PO}_{4}$; Czapek (Wiseman, 1975) modified by removing the $\mathrm{NaNO}_{3}$, $\mathrm{KCl}$, and $\mathrm{Fe}_{2}\left(\mathrm{SO}_{4}\right)_{3}$ salts; and the $\mathrm{CP}$ medium (Peixoto et al., 2003). Soluble starch was used in all the tested media as a carbon source. After preparation, all the submerged media had their pHôs adjusted to 6.5. Subsequently, the fungus inoculum was performed, and the cultures were incubated in a bacteriological incubator at $30{ }^{\circ} \mathrm{C}$ for three days. After the incubation, the cultures were filtered, and the amylolytic activity was determined. The medium in which the highest activity was observed was chosen for the subsequent determinations.

\subsection{Determination of the Salt Solution in the Fungus Cultivation for the Production of Amylases}

After determining the submerged culture medium, the concentration of the salt solution was changed to $0.05 \%(\mathrm{~m} / \mathrm{v})$ Wesson Salts, CP Salts, Wesson Salts with CP Salts and modified SR salts solution. Subsequently, the fungus inoculum was performed, and the cultures were incubated in a bacteriological incubator at $30{ }^{\circ} \mathrm{C}$ for three days. After the incubation, the cultures were filtered, and the amylolytic activity was determined.

\subsection{Determination of the Time for Cultivation of Aspergillus sp. M1.7.2}

The fungus was incubated at $30{ }^{\circ} \mathrm{C}$ and $\mathrm{pH} 6.5$, in $\mathrm{CP}$ submerged culture medium (Peixoto et al., 2003) containing the predetermined salt solution and $1.5 \%$ starch as a carbon source. The cultures were incubated in a bacteriological incubator from one to nine days under static conditions. A triplicate was removed every 24 hours, the cultures were filtered, and the extracellular amylolytic activity was determined.

\subsection{Determination of the Nitrogen Source of the Culture Medium}

In a standardized environment, the nitrogen source was varied using $0.8 \%(\mathrm{w} / \mathrm{v})$ casein peptone, $0.8 \%(\mathrm{w} / \mathrm{v})$ yeast extract and $0.04 \%(\mathrm{w} / \mathrm{v})$ yeast extract plus $0.04 \%(\mathrm{w} / \mathrm{v})$ of casein peptone. Subsequently, the fungus inoculum was performed, and the cultures were incubated in a bacteriological incubator at $30^{\circ} \mathrm{C}$ for six days. After the incubation, the cultures were filtered, and the amylolytic activity was determined. 
2.10 Determination of the Initial pH of the Medium and the Concentration of the Fungus Inoculum

The fungus under study was incubated in CP submerged medium at various initial pHs: 4.0, 4.5, 5.0, 5.5, and 6.0. The incubation was accomplished at $30{ }^{\circ} \mathrm{C}$, stationary in a bacteriological oven. Concomitantly, the effect of spore concentration in the inoculum was verified for the greatest production of enzyme. That is, $1 \mathrm{~mL}$ of spore solution was inoculated at all $\mathrm{pHs}$ in cultures at the following concentrations: $1.1 \times 10^{5} 5.6 \times 10^{4}, 1.0 \times 10^{4}$ and $5.0 \times 10^{3}$ of spores $/ \mathrm{mL}$.

\subsection{Effect of Carbon Source on Amylolytic Production}

Ten different carbon sources were analyzed in the culture medium of Aspergillus sp. M1.7.2 at a concentration of $1.5 \%(\mathrm{w} / \mathrm{v})$. These sources were soluble starch (Dinâmica®), glucose (Isofar®), Musa spp. ñPrata-Anãò genomic group AAB pulp and peel, English potato pulp and peel (Solanum tuberosum), cassava pulp and peel (Manihot esculenta), corn starch (Maizena®) and ground corn (Zea mays).

\subsection{Effect of $\mathrm{pH}$ and Temperature on Enzyme Activity}

The ideal conditions of $\mathrm{pH}$ and temperature of the enzymatic assay were evaluated by determining amylase activity at temperatures ranging from $40{ }^{\circ} \mathrm{C}$ to $75^{\circ} \mathrm{C}$, at $5{ }^{\circ} \mathrm{C}$ intervals, using $100 \mathrm{mM}$ sodium acetate buffers for the $\mathrm{pH} 4.5$; 5.0 and 5.5; and $100 \mathrm{mM}$ sodium phosphate for $\mathrm{pH}$ 6.0, 6.5, 7.0 and 7.5 .

\subsection{Stability of Amylases with Respect to Temperature}

The temperature stability of the enzymes was evaluated by incubating the enzyme for 30, 60, 90 and 120 minutes (in the absence of substrate) at temperatures from $50{ }^{\circ} \mathrm{C}$ to $70{ }^{\circ} \mathrm{C}$, with intervals of $5{ }^{\circ} \mathrm{C}$. Subsequently, the enzymatic activity of each sample was determined under ideal conditions of $\mathrm{pH}$ and temperature.

\subsection{Stability of Amylases at pH}

The variation of enzyme stability with $\mathrm{pH}$ was evaluated by incubating the enzyme extract in $100 \mathrm{mM}$ sodium acetate buffer ( $\mathrm{pH} 4.5 ; 5.0$ and 5.5) and $100 \mathrm{mM}$ sodium phosphate buffer (pH 6.0; 6.5 and 7.0) for 30, 60, 90 and 120 minutes in an ice bath. The enzymatic activity of the samples was determined in $200 \mathrm{mM}$ sodium phosphate buffer $\mathrm{pH} 6.0$ at 65

\section{${ }^{\circ} \mathrm{C}$.}

\subsection{Effect of Ions on Enzyme Activity}

To study the effect of ions on amylolytic activity, 5 and $10 \mathrm{mM}$ solutions (final concentrations) of $\mathrm{CuSO}_{4} .5 \mathrm{H}_{2} \mathrm{O}, \mathrm{NH}_{4} \mathrm{Cl}$, $\mathrm{CoCl}_{2} \cdot 6 \mathrm{H}_{2} \mathrm{O}, \mathrm{KCl}, \mathrm{NaCl}, \mathrm{MgCl}_{2} \cdot 6 \mathrm{H}_{2} \mathrm{O}, \mathrm{ZnCl}_{2}, \mathrm{AgNO}_{3}$, $\mathrm{KH}_{2} \mathrm{PO}_{4}$ and EDTA were incubated with the enzyme and the substrate in a water bath under ideal conditions.

\subsection{Statistical Analysis}

All the experiments were performed independently and in triplicate. The results presented are the average of the values obtained. The standard deviations were calculated using Excel 2007.

\section{RESULTS AND DISCUSSION}

\subsection{Sampling, Isolation and Identification of Fungi}

Twenty-one filamentous fungi were isolated and identified. M1.1, M1.2, M1.3, M1.4, M1.5, M1.6, M1.7.1, M1.7.2, M1.8, M1.9, M1.10, M1.11, M1.12 were isolated from the tree bark. The M2.1.1, M2.1.2, M2.2, M2.3, M2.4, M2.5 microorganisms were obtained from the fruit peels, and the M3.1, M3.2 organisms were isolated from the decomposing leaf.

The colors of the colonies varied between shades of green, black, white and blue, some with pigmentation secretion. All the microorganisms had a smooth bottom, with the exception of M3.2. Four possible genera were identified. Aspergillus was the most common, with fourteen strains being identified, followed by the Penicillium genus, which was found in two of the three materials collected, with four strains being identified. Only one Mucor and one Neurospora organism were identified. One fungus did not have its genus recognized, as is shown in Table 1.

The results obtained regarding the collected genus were similar to those found by several authors. The predominantly isolated fungi found in sampling made in various parts of the country were cosmopolitan Aspergillus and Penicillium (Cavalcanti et al., 2006; Gomes, 2007; Benassi et al., 2014; Almeida, 2015; Griebeler, et al., 2015, Pasin et al., 2020).

Table 1 - Analysis of macroscopic morphological characteristics of isolated filamentous fungi and possible genus of the microorganisms.

\begin{tabular}{|c|c|c|c|c|}
\hline Code & Color & Texture & Pigmentation & Genus \\
\hline M1.1 & Green & Powdery & Absence & Aspergillus \\
\hline M1.2 & Black & Powdery & Absence & Aspergillus \\
\hline M1.3 & Green & Powdery & Absence & Aspergillus \\
\hline M1.4 & Green & Velvety & Absence & Penicillium \\
\hline M1.5 & White & Cotton & Presence & - \\
\hline M1.6 & Black & Powdery & Absence & Aspergillus \\
\hline M1.7.1 & Green & Powdery & Absence & Aspergillus \\
\hline M1.7.2 & Green & Powdery & Absence & Aspergillus \\
\hline M1.8 & Green & Furfuraceous & Presence & Penicillium \\
\hline M1.9 & Black & Cotton & Absence & Neurospora \\
\hline M1.10 & Blue & Velvety & Absence & Penicillium \\
\hline M1.11 & Green & Powdery & Absence & Aspergillus \\
\hline M1.12 & Black & Powdery & Absence & Aspergillus \\
\hline M2.1.1 & Black & Powdery & Absence & Aspergillus \\
\hline M2.1.2 & Black & Powdery & Absence & Aspergillus \\
\hline M2.2 & Green & Velvety & Presence & Penicillium \\
\hline M2.3 & Black & Powdery & Absence & Aspergillus \\
\hline M2.4 & Black & Powdery & Absence & Aspergillus \\
\hline M2.5 & Black & Powdery & Absence & Aspergillus \\
\hline M3.1 & White & Cotton & Absence & Mucor \\
\hline M3.2 & Black & Powdery & Presence & Aspergillus \\
\hline
\end{tabular}


Pelczar et al. (1997) divided the organisms into three classes, according to the ideal growth temperature: psychrophiles (temperatures below $20{ }^{\circ} \mathrm{C}$ ), mesophiles (between 25 and $40{ }^{\circ} \mathrm{C}$ ) and thermophiles (temperatures above $40{ }^{\circ} \mathrm{C}$ ). Mesophiles form the group that involves a large portion of the microorganisms. Although they exhibit excellent growth at moderate temperatures, some of them can grow at higher temperatures. These are called thermotolerants.

After the analysis of growth at different temperatures, it was concluded that all the isolated microorganisms are mesophiles because they grew more rapidly at $35^{\circ} \mathrm{C}$, as can be seen in Table 2. Despite this observation, some fungi were able to develop at higher temperatures, including thirteen fungi (M1.1, M1.3, M1.6, M1.7.1, M1.7.2, M1.8, M1.11, M1.12, M2.1.1, M2.1.2, M2.4, M2.5, M3.2) that grew at $40{ }^{\circ} \mathrm{C}$, seven (M1.7.1, M1.7.2, M1.8, M1.11, M2.1.1, M2 .1.2, M2.4) that grew at $45^{\circ} \mathrm{C}$, and finally three microorganisms (M1.7.1, M1.8, $\mathrm{M} 2.1 .1$ ) that grew at $50{ }^{\circ} \mathrm{C}$. These filamentous fungi were classified as thermotolerant. These studies corroborate the results obtained by Pasin et al. (2014), Benassi et al. (2014) and Pasin et al. (2020).

Table 2 - Growth rate $(\mathrm{mm} / \mathrm{h})$ of filamentous fungi isolated at different temperatures.

\begin{tabular}{ccccc} 
& \multicolumn{5}{c}{ Growth rate $(\mathbf{m m} / \mathbf{h})$ at } \\
Code & $\mathbf{3 5}{ }^{\circ} \mathbf{C}$ & $\mathbf{4 0}{ }^{\circ} \mathbf{C}$ & $\mathbf{4 5}{ }^{\circ} \mathbf{C}$ & $\mathbf{5 0}^{\circ} \mathbf{C}$ \\
M1.1 & 0.29 & 0.08 & - & - \\
M1.2 & 0.17 & - & - & - \\
M1.3 & 0.29 & 0.17 & - & - \\
M1.4 & 0.06 & - & - & - \\
M1.5 & 0.17 & - & - & - \\
M1.6 & 0.35 & 0.18 & - & - \\
M1.7.1 & 0.24 & 0.12 & 0.11 & 0.10 \\
M1.7.2 & 0.33 & 0.14 & 0.12 & - \\
M1.8 & 0.35 & 0.35 & 0.17 & 0.06 \\
M1.9 & 0.06 & - & - & - \\
M1.10 & 0.08 & - & - & - \\
M1.11 & 0.28 & 0.12 & 0.04 & - \\
M1.12 & 0.19 & 0.10 & - & - \\
M2.1.1 & 0.31 & 0.28 & 0.04 & 0.02 \\
M2.1.2 & 0.34 & 0.19 & 0.02 & - \\
M2.2 & 0.06 & - & - & - \\
M2.3 & 0.19 & - & - & - \\
M2.4 & 0.25 & 0.19 & 0.02 & - \\
M2.5 & 0.23 & 0.08 & - & - \\
M3.1 & 1.11 & - & - & - \\
M3.2 & 0.21 & 0.05 & - & - \\
\hline
\end{tabular}

Fungi that are resistant to high temperatures are interesting from a biotechnological point of view because they are capable of producing enzymes with high thermal stability. However, a low heat tolerance does not imply that the organism does not produce thermostable enzymes; the low temperature tolerance is frequently due to the complex membrane systems (Gomes et al., 2007).

\subsection{Selection of Filamentous Amylase-Producing Fungi}

On the basis of the results of the qualitative assessment of amylases produced by fungi, four microorganisms were chosen, namely: Aspergillus sp. M1.3, Aspergillus sp. M1.7.2, Penicillium sp. M1.8 and Aspergillus sp. M1.11 for cultivation in submerged CP and analysis of amylolytic activity. As can be seen in Figure 1, the highest amylase activity was observed for Aspergillus sp. M1.7.2, which was 4118 total U, followed by microorganisms M1.3 and M1.11 with enzymatic activities close to 296 and 274 total U, respectively, representing approximately $7 \%$ of the activity of isolate M1.7.2. Very low amylolytic activity, only 5.27 U total, was observed for the only strain belonging to the genus Penicillium (M1.8).

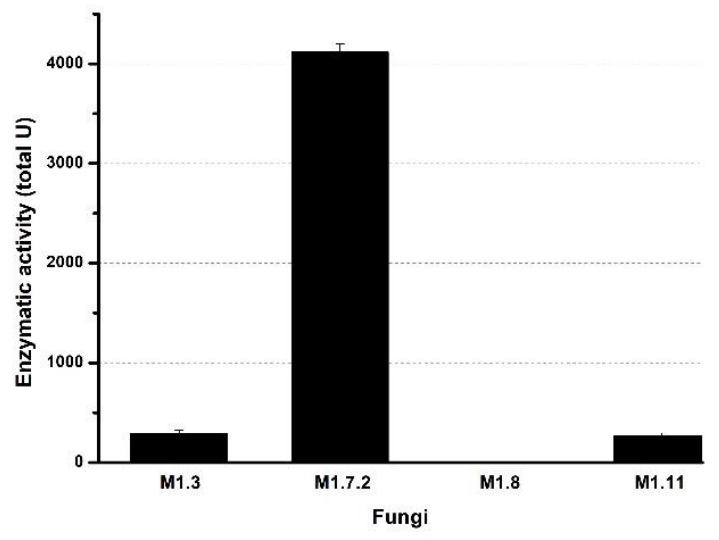

Figure 1 - Selection of the isolated filamentous fungi that produced amylases in a submerged $C P$ culture medium.

Almeida (2015), Silva (2009) and Facchini (2010) demonstrated the superiority of Aspergillus filamentous fungi, compared to other genera, in the production of enzymes. Almeida (2015) reports that the amylolytic activity achieved by Aspergillus brasiliensis under identical conditions corresponded to $24.36 \%$ of the activity shown by the filamentous fungus Aspergillus sp. M1.11 and about $2.1 \%$ of the activity of Aspergillus sp. M1.7.2. Silva (2009) observed a considerably greater amylolytic activity for Aspergillus niveus than that of Aspergillus sp. M1.3 and M1.11. However, it corresponded to only two-fifths of the activity of Aspergillus sp. M1.7.2. Under these circumstances, Aspergillus sp. M1.7.2 was selected to optimize the production of amylases.

\subsection{Definition of the culture medium and the salt solution for cultivation of the selected fungus}

In the laboratory, the growth of microorganisms is achieved by inoculation in culture medium, which can be complex or simple, and this medium must meet the nutritional needs of microorganisms, providing them with nitrogen sources, essential inorganic ions, water and, mainly, a carbon source. It is worth mentioning that the nutrients offered have the power to induce or inhibit enzymatic production and, consequently, the growth of the fungus (Borzani et al., 2001).

Very different reactions were observed for the four media tested, thus demonstrating the importance they have on the production of enzymes. A high amylolytic activity was observed when the Aspergillus sp. M1.7.2 was cultivated in the CP medium (4229.88 U total), follow to the modified SR medium 
(722.43 U total) and modified Khanna (321.10 U total) and the very low activity of the Czapek medium (15.16 Total U) (Table 3).

Table 3 - Determination of the culture medium for amylolytic production by the fungus Aspergillus sp. M1.7.2.

\begin{tabular}{|l|c|}
\hline \multicolumn{1}{|c|}{ Medium } & Activity (total U) \\
\hline CP & $4229.78 \pm 2.78$ \\
\hline Modified SR & $722.43 \pm 2.24$ \\
\hline Modified Khanna & $321.10 \pm 2.79$ \\
\hline Modified Czapeck & $15.16 \pm 2.45$ \\
\hline
\end{tabular}

The medium with the best performance for the microorganism was that in which the yeast extract, at a concentration of $0.8 \%(\mathrm{~m} / \mathrm{v})$, was the only source of nitrogen. The salts added to the medium were dipotassium phosphate $(0.03 \%)$ and hydrated magnesium sulfate $(0.05 \%)$; all the other media contained these two salts in greater concentrations and also contained other salts. This fact represents a greater savings in the cost of producing enzymes.

Almeida (2015) tested the Khanna, SR and CP media without any modifications. For Aspergillus brasiliensis, the greatest production of amylases was observed under static conditions in SR, CP and Khanna media, respectively, where the variation in activity between the two best media was very small, considering the difference between the compositions. The same author found a greater enzyme production with stirring in $\mathrm{CP}$, SR and Khanna media, respectively, for Rhizopus oryzae. Facchini (2010) verified the low cellulolytic induction in Czapek culture medium for Aspergillus terreus and Aspergillus japonicus fungi. Silva (2009) found that the best medium for the production of amylases was Khanna, followed by the SR medium. In addition, he found that the Czapek medium was irrelevant in the production of amylases by Aspergillus niveus.

Borzani et al. (2001) explained that sources of only carbon and nitrogen are often insufficient and require the addition of inorganic compounds. These compounds are often required in very low amounts. Sulfur, phosphorus, magnesium and potassium ions are important, and they are essential for good microbial growth.

The solution of modified CP and SR salts is formed by dipotassium phosphate and hydrated magnesium sulfate, compounds which have been described as essential by the authors. According to Corrêa (2006), the Wesson salt contained copper sulfate heptahydrate, calcium carbonate, tricalcium phosphate, potassium iodide, ferric phosphate, potassium and aluminum sulfate, magnesium sulfate, sodium chloride, manganese sulfate, potassium chloride, monopotassium phosphate and sodium fluoride. The essential compounds mentioned by the author for the production of enzymes were present among the salts more than once.

Among the salt solutions tested, the highest enzymatic activity, 5076.6 total $\mathrm{U}$, was observed for the $\mathrm{CP}$ medium after three days at $35^{\circ} \mathrm{C}$. The second highest enzyme activity was obtained using the salt solution containing $\mathrm{CP}$ medium and Wesson salts, 3086.6 total U. In a medium in which the SR salt solution was used, a total activity of 2366 total U was observed, and only 373.4 total $U$ were observed in the medium containing
Wesson salts. Again, the results obtained indicate greater savings for the production of amylases by Aspergillus sp. M1.7.2 (Table 4).

Table 4 - Determination of salt solution to the culture medium for amylolytic production by the fungus Aspergillus sp. M1.7.2.

\begin{tabular}{|l|c|}
\hline \multicolumn{1}{|c|}{ Salt solution } & Activity (total U) \\
\hline CP & $5076.60 \pm 2.48$ \\
\hline CP + Wesson & $3086.62 \pm 2.35$ \\
\hline SR & $2366.51 \pm 2.12$ \\
\hline Wesson & $373.40 \pm 1.98$ \\
\hline
\end{tabular}

\subsection{Determination of the cultivation time of Aspergillus sp. M1.7.2 for amylolytic enzyme production}

The ideal cultivation time varies with the fungus species and growing conditions. In the test performed, a rapid increase in amylolytic activity was observed over time until the sixth day of cultivation, slowly decreasing after this period, and an activity of 8098 total $\mathrm{U}$ was verified after six days at $30^{\circ} \mathrm{C}$ without stirring (Figure 2).

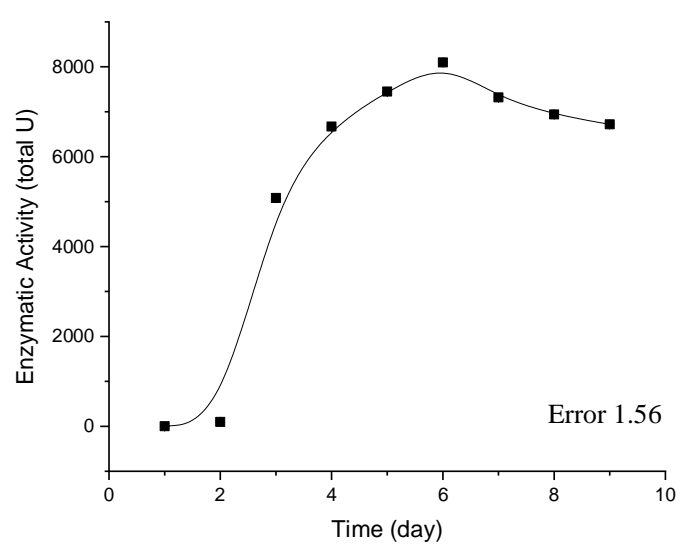

Figure 2 - Determination of the Time for Cultivation of Aspergillus sp. M1.7.2.

According to Santos (2008), fermentation by filamentous fungi occurs in two distinct morphological phases, which are the tropophase, the stage where the growth of the microorganism (from the germination of the spores to the formation of the mycelium) occurs, and the idiophase stage, in which product formation occurs. The cultivation time of a fungus directly and significantly influences the production of the enzyme. If incubated for a short period of time, the enzyme activity can be much lower than its maximum activity because it will be in the tropophase or vegetative phase. Likewise, incubation for prolonged periods can deplete nutrients and cause a decrease in enzyme activity.

Silva (2009) observed that the highest amylase activity occurred on the third day of cultivation. The author justified his result by proposing that, at the end of the exponential growth phase when the sugars in the medium were not easily assimilated, the fungal growth decreased to guarantee survival, 
and it was induced to produce a large amount of enzymes, enough to degrade many molecules of starch to meet its nutritional needs.

Pasin (2015) observed that the greatest production of amylase by Aspergillus japonicus occurred after four days of cultivation without stirring, a result similar to those obtained in our work. It also occurred after three days when stirred. However, the greatest activity occurred under static conditions. Nwagu and Okolo (2011a) found that the fifth day of cultivation at $30^{\circ} \mathrm{C}$ was the best time for the Fusarium sp. fungus. A similar result was obtained by Almeida (2015), who, in his research, performed the day test on two filamentous fungi Aspergillus brasiliensis and Rhizopus oryzae, and the ideal time for each was five and four days, respectively. Paris et al. (2012) found that the best growth time for the production of amylases, proteases and lipases by Aspergillus niger was on the sixth day.

3.5 Determination of the nitrogen source of the submerged culture medium for the production of amylase

Among the nitrogen sources tested, the lowest production of amylases was obtained with the casein peptone, which yielded an activity of 3995 total U. Again, the result led to the continuation of the use of yeast extract, the original nitrogenous component of the $\mathrm{CP}$ medium, whose use yielded a total enzymatic activity was $8425 \mathrm{U}$, which is about $47.7 \%$ greater than any other nitrogen source (Table 5).

Table 4 - Determination of nitrogen source to the culture medium for amylolytic production by the fungus Aspergillus sp. M1.7.2.

\begin{tabular}{lc}
\hline \multicolumn{1}{c}{ Nitrogen sources } & Activity (total U) \\
Yeast Extract & $8425.65 \pm 1.58$ \\
Casein Peptone & $3995.78 \pm 1.22$ \\
Yeast extract + Casein Peptone & $4049.24 \pm 1.74$
\end{tabular}

Nitrogen is essential in the synthesis of amino acids, nitrogenous bases present in nucleic acids, vitamins and glucosamine, a component of chitin. Both natural and synthetic media must have at least one source of nitrogen to enable the production of enzymes by the fungus and, consequently, growth (Veron, 2016).

Yeast extract was also defined as the best source of nitrogen to support the production of amylases by the fungus Talaromyces trachyspermus $\mathrm{T} 10-5$, as observed by Veron (2016). Nwagu and Okolo (2011b) cultivated Aspergillus fumigatus in medium containing several organic sources of nitrogen. The best source was yeast extract, this source being about twice as good as the casein peptone. Nwagu and Okolo (2011a) also cultivated Fusarium sp. in culture media with various sources of nitrogen, such as amino acids, yeast extract, casein peptone and soybean meal. The soybean meal was the source that best induced amylolytic activity; the activity obtained in the presence of the peptone was slightly greater than that obtained when using the yeast extract.

3.6 Determination of the inoculum concentration and the initial $\mathrm{pH}$ of the medium

The highest concentration of spores in the inoculum of the medium was the most favorable with regard to enzymatic activity. Proportionality was noted, where the decrease in the quantity of spores lead to a decrease in amylolytic activity (Figure 3).

The initial $\mathrm{pH}$ of the culture medium favorable for the growth of the fungus and production of amylase was 5.5, a result similar to that observed by Pasin (2015). However, that author observed acidification of the medium during cultivation, a process opposite that observed in the present work.

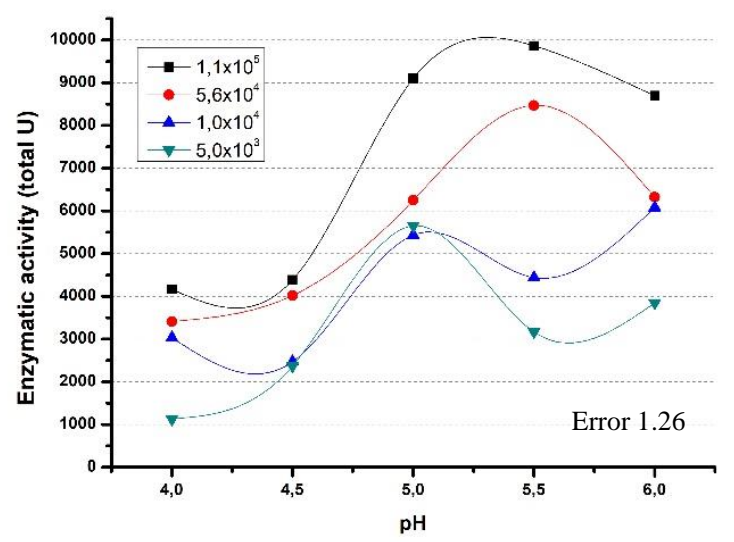

Figure 3 - Amylolytic activity of Aspergillus sp. M1.7.2 as a function of the initial $\mathrm{pH}$ of the culture medium and the concentration of spores in the inoculum.

Ming Chu et al. (1992) explained that changes in the $\mathrm{pH}$ of the culture medium during the growth of the fungus are related to the consumption of the substrate. The medium becomes more basic when organic nitrogen (amino acids and peptides) is being incorporated or more acid when ammonium ions are consumed. Dutton et al. (1996) also suggested that the acidification of the culture medium can be caused by the production of acids, such as oxalic acid, which increases the availability of metal ions that favor amylase activity because it is a chelating agent.

Freitas et al. (2014) observed a small influence of the initial $\mathrm{pH}$ of the medium on the final amylolytic activity; that is, the production of amylases was not inhibited by the $\mathrm{pH}$ of the medium in Fusarium sp.. Sales et al. (2010) analyzed the effect of the initial spore concentration on the production of several cellulases by the fungus Aspergillus aculeatus, and they observed that the highest concentration of spores favored the production of four of the five enzymes tested.

In the experiments carried out by Spier (2005) with the Aspergillus niger, an inverse effect was observed in the production of amylases by increasing the concentration of inoculum; that is, a larger number of spores resulted in a decrease in enzymatic activity. These results were obtained by solid state fermentation. Silva (2009) observed that the ideal concentration for Aspergillus niveus was $5 \times 10^{5}$ spores $/ \mathrm{mL}$, an intermediate concentration among those tested by the author and close to the ideal concentration verified in this study.

\subsection{Effect of variation of carbon source on enzyme activity}

The best source of carbon among those tested was the English potato (Solanum tuberosum) pulp. The total amylolytic activity obtained was 9,538.32 U, an activity slightly higher than that obtained with soluble starch, which was 8551.93 total U. 
The other sources also induced high activities, such as potato skins, cassava and cassava skins, corn and bananas, as is shown in Figure 4. All the sources contributed to high amylase secretion, except for glucose. This source is described in the literature as a classic catabolic repressor, which acts on the regulation of gene expression at transcriptional levels (Carlson, 1987; Benassi et al., 2012).

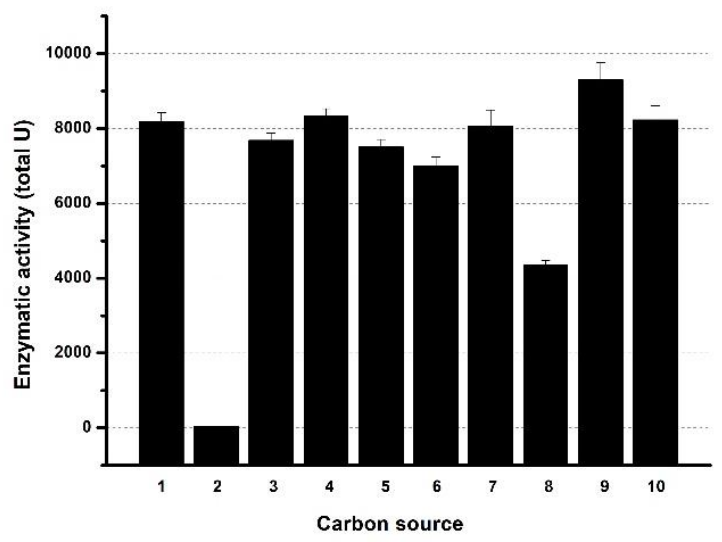

Figure 4 - Amylolytic activity of Aspergillus sp. M1.7.2 as a function of the carbon source of the submerged culture medium.

Note: (1) soluble starch; (2) D-glucose; (3) corn starch; (4) corn; (5) cassava; (6) cassava skins; (7) banana; (8) banana skins; (9) potato and (10) potato skins.

The high cost associated with the production of enzymes is a major obstacle to their application in industrial processes. The carbon sources usually used in fermentations are the elements that most contribute to this cost (Pandey et al., 1999). The production of amylases is commonly induced by the presence of starch (or some of its hydrolysis products, such as maltose), either in soluble or native form (present in seeds, tubers, among others). Currently, several studies searching for economically viable carbon sources, such as agro-industrial waste, are in progress. The use of these compounds as a carbon source for the cultivation of microorganisms for the purpose of enzyme production significantly reduces the cost of obtaining the enzyme, in addition to contributing to the reduction of environmental impacts (Gonçalves, 2016).

Nwagu and Okolo (2011b) tested the effects of a diversity of starches and sugars on enzyme activity produced by Aspergillus fumigatus, and they obtained good results for corn, potato and cassava starch. The catabolism induced by these carbon sources (native starch) was better than that obtained with soluble starch and the various sugars tested. Benassi et al. (2012) explained that the agro-industrial residues used were probably hydrolyzed in the culture medium to maltooligosaccharides by constitutive amylases. These can act as true inducers of gene expression. Despite the fact that the result obtained with the potato starch was superior to that observed with soluble starch, it was decided to continue using the latter as a standard carbon source for cultivation of the isolated microorganism M1.7.2.

3.8 Effect of $\mathrm{pH}$ and temperature on the activity of amylases produced by Aspergillus sp. M1.7.2

The amylolytic activity of the enzyme extract from Aspergillus sp. M1.7.2 was maximum at $65{ }^{\circ} \mathrm{C}$ and $\mathrm{pH} 6.0$ (9447.9 total U). High enzymatic activities were obtained at all the $\mathrm{pH}$ and temperature ranges analyzed. Activities greater than $70 \%$ of the maximum activity were obtained at $\mathrm{pH} 5.0$ and 6.5 and temperatures of $45^{\circ} \mathrm{C}$ to $70{ }^{\circ} \mathrm{C}$, giving these enzymes applicability in various industrial processes. The findings of this experiment are in agreement with those of other amylases described in the literature. Silva et al. (2000) and Pasin et al. (2017) found an optimal activity at $65{ }^{\circ} \mathrm{C}$ and $\mathrm{pH}$ 5.0.for the amylases produced by Aspergillus fumigatus and the purified glucoamylases of Aspergillus japonicus, respectively.

Ali et al. (2014) and Nwagu and Okolo (2011b) observed that the amylases produced by Aspergillus gracilis and Aspergillus fumigatus possessed greater activity at $60{ }^{\circ} \mathrm{C}$ and an ideal $\mathrm{pH}$ of 5.5. The amylases produced by Paecilomyces variotti, as described by Michelin et al. (2010), exhibited greater catalytic power at $60{ }^{\circ} \mathrm{C}$ and $\mathrm{pH} 4.0$. High activities were also obtained at $\mathrm{pH} 4.5$ and 5.0, as was observed for the amylases of Aspergillus sp. M1.7.2. Carrasco et al. (2017) observed greater catalytic activities for Üglycosidase secreted by the yeast Dioszegia fristingensis at $\mathrm{pH} 5.5$ - 6.5. According to Oliveira, Watanabe, and Rodrigues (2011), the optimal activity of the amylases of Penicillium sp. was obtained at $55^{\circ} \mathrm{C}$ and $\mathrm{pH}$ 6.5. For the thermotolerant Fusarium sp. cultivated by Nwagu and Okolo (2011a), the best conditions were $\mathrm{pH} 6.5$ and $50{ }^{\circ} \mathrm{C}$.

\subsection{Enzyme Thermostability}

A high stability at $50{ }^{\circ} \mathrm{C}$ was observed for the enzymes, with a half-life greater than 120 minutes. At $55^{\circ} \mathrm{C}$, an activity greater than $50 \%$ was observed for more than 60 minutes. After 120 minutes at this temperature, the enzyme still retained about $30 \%$ of its activity. However, the half-life was less than 30 minutes above $60{ }^{\circ} \mathrm{C} ; 98.89 \%$ of the activity was lost when exposed for 120 minutes at this temperature, as is shown in Figure 5.

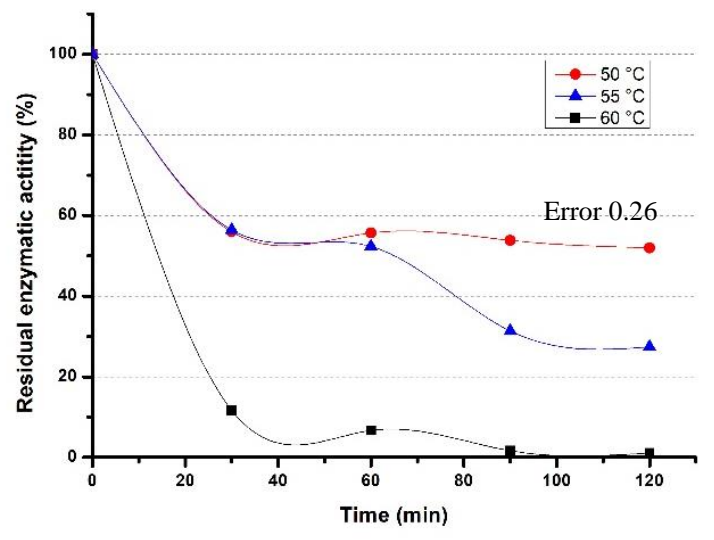

\section{Figure 5 - Variation of the stability of the enzyme with} temperature and reaction times.

A high stability at $50{ }^{\circ} \mathrm{C}$ and $55^{\circ} \mathrm{C}$ was observed for the enzymes produced by Paecilomyces variotii. Their activities were considerably lower at $60^{\circ} \mathrm{C}$ (Michelin et al., 2010). The Ŭ amylase produced by Syncephalastrum racemosum was stable at $55^{\circ} \mathrm{C}$ and $60{ }^{\circ} \mathrm{C}$ (Freitas et al., 2014). The amylases produced by Aspergillus niger exhibited greater resistance at $60{ }^{\circ} \mathrm{C}$, with a half-life 40 minutes at this temperature (Pereira, 2015). The catalytic activity of the Üglucosidases produced by Dioszegia fristingensis decreased by $70 \%$ after two hours of incubation at $50{ }^{\circ} \mathrm{C}$ (Carrasco et al., 2017). 


\section{$3.10 \mathrm{pH}$ stability}

The amylases possessed a high stability to variations in $\mathrm{pH}$, losing less than $30 \%$ of their activity after 120 minutes of incubation at all the $\mathrm{pHs}$ tested. The enzyme was activated at pHs $4.5 ; 5.0 ; 6.0 ; 6.5$ and 7.0 when exposed for 30 minutes (Figure 6). Similar stability has been described by Pasin et al. (2017) for glucoamylases produced by $A$. japonicus. These enzymes retained more than $80 \%$ of their activity during an hour of incubation. Benassi et al. (2014) also observed a high stability between $\mathrm{pH} 3.0$ and 6.0 for the amylases produced by $A$. phoenicis.

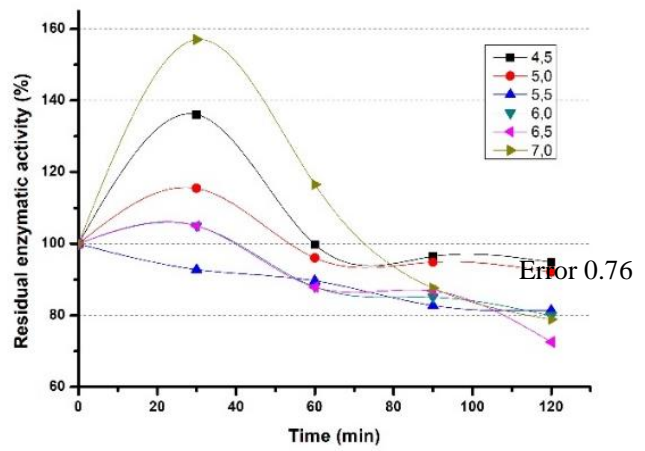

Figure 6 - Variation of the stability of the enzyme with pH and reaction times.

\subsection{Effect of ions on enzyme activity}

The enzymes produced by Aspergillus sp. M1.7.2 were active in the presence of $\mathrm{NaCl}, \mathrm{NH}_{4} \mathrm{Cl}, \mathrm{MgCl}_{2}$ and $\mathrm{KH}_{2} \mathrm{PO}_{4}$ at concentrations of 5 and $10 \mathrm{mM}$. The greatest activity was observed at a concentration of $10 \mathrm{mM}$. The activation by $10 \mathrm{mM}$ $\mathrm{KCl}, 5 \mathrm{mM} \mathrm{NaCl}$ and $\mathrm{MgCl}_{2}$ at both concentrations was not very significant. However, activation by $\mathrm{NH}_{4} \mathrm{Cl}$ was greater; the activity of the enzyme extract increased by up to $20 \%$. $\mathrm{KH}_{2} \mathrm{PO}_{4}$ stood out because an increase in enzyme activity by more than 50 and $60 \%$ at concentrations of 5 and $10 \mathrm{mM}$, respectively, was observed. When the concentrations of the other compounds tested, such as $\mathrm{ZnCl}_{2}, \mathrm{AgNO}_{3}, \mathrm{CuSO}_{4}, \mathrm{CoCl}_{2}$ and EDTA, were increased, a decrease in enzymatic activity was observed (Figure $6)$.

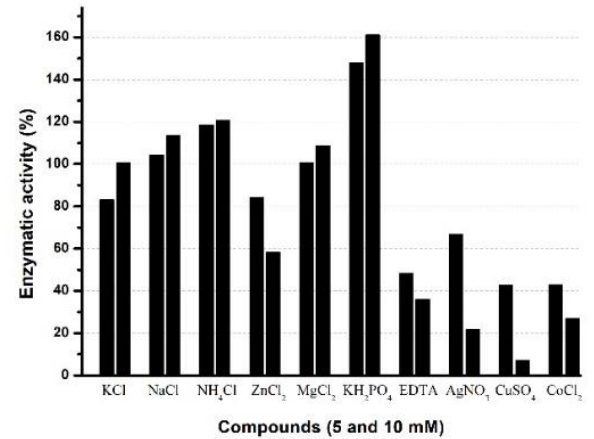

Figure 7 - Effect of ions and EDTA on enzyme activity.

Metal ions are important during enzymatic synthesis because they are incorporated into amylases and contribute to the conformation and catalytic activity of these enzymes (Nwuagu et al., 2011a). The work of Ezeji et al. (2005) presented similar results regarding the activities against $\mathrm{Co}^{2+}$ and $\mathrm{Zn}^{2+}$ ions. Pires et al. (2012) observed that the presence of EDTA significantly reduced the activity of the enzyme, as well as suggesting that the enzymes used are dependent on $\mathrm{Ca}^{2+}$ ions. For the enzymes studied by those authors, the addition of $\mathrm{CuSO}_{4}$ to the reaction was observed to significantly inhibit the activity of amylases. Their results were similar to those observed in the present work.

However, Nwagu and Okolo (2011b) observed that the amylases produced by Aspergillus fumigatus were activated by $\mathrm{Cu}^{2+}$ and $\mathrm{Zn}^{2+}$ ions at a concentration of $2 \mathrm{mM}$, results that are inconsistent with those obtained in this work. Pasin et al. (2017) verified enzymatic activation by the $\mathrm{KH}_{2} \mathrm{PO}_{4}$ salt. However, more significant activation was verified in the presence of $\mathrm{MnCl}_{2}$; they observed the same effect as that observed for $\mathrm{KH}_{2} \mathrm{PO}_{4}$ regarding the enzyme activity in the present work, with an increase in the activity by about 50 and $60 \%$ at the concentrations of 5 and $10 \mathrm{mM}$, respectively. This salt repressed the enzymatic activity of the fungus Paecilomyces variotii by almost 70\%, as verified by Michelin et al. (2010); an opposite effect was also observed regarding the use of $\mathrm{CoCl}_{2}$, which substantially activated the amylases of $P$. variotii and deactivated those of Aspergillus sp. M1.7.2.

\section{Conclusions}

There is a diversity of microorganisms to be isolated, many of them with a potential for industrial application, such as Aspergillus sp. M1.7, which stands out as a potential amylaseproducing organism with desirable characteristics for applications in biotechnological processes. The cultivation of the microorganism was standardized under ideal conditions for enzyme production and throughout the standardization. A large amount of amylase secretion by the fungus was observed, thus dispensing with extracellular enzyme extraction steps. As for their physicochemical characteristics, a similarity with the enzymes described in the literature was observed; however, with more desirable characteristics, as well as temperature stability and a wide range of $\mathrm{pH}$ stability. The amylases produced also exhibited excellent activation, especially with $\mathrm{KH}_{2} \mathrm{PO}_{4}$, noting that the inclusion of $\mathrm{NH}_{4} \mathrm{Cl}$ also caused an increase in enzyme activity. Thus, a great potential for biotechnological and industrial use in the future was demonstrated.

\section{Acknowledgment}

This research was registered in the National System for the Management of Genetic Heritage and Associated Traditional Knowledge (SisGen), number A64AD93. This work was part of the undergraduate scientific iniciation scholarship CNPq/PIBIC.

\section{R E F E R E N C E S}

ALI, I.; AKBAR, A.; YANWISETPAKDEE, B.; PRASONGSUK, S.; LOTRAKUL, P.; PUNNAPAYAK, H. Purification, characterization, and potential of saline waste-water remediation of a polyextremophilic $\breve{U}$ amylase from an obligate halophilic Aspergillus gracilis. BioMed Research International, v. 2014, p. 1-7, Mai. 2014. 
ALMEIDA, P. Z. Diversidade do potencial amilolítico em fungos filamentosos: purificação e caracterização de uma glucoamilase de Aspergillus brasiliensis. 2015. 137p. Dissertação (Mestrado em ciências) ï Faculdade de filosofia, ciências e letras de Ribeirão Preto, Universidade de São Paulo, Ribeirão Preto, 2015.

BENASSI, V. M.; LUCAS, R. C.; MICHELIN, M.; JORGE, J. A.; TERENZI, H. F.; POLIZELI, M. L. T. M. Production and action of an Aspergillus phoenicis enzymatic pool using different carbon sources. Campinas, SP. Braz. J. Food Technol. v. 15, n. 3, p. 253-260, Set. 2012.

BENASSI, V. M. Imobilização covalente e não-covalente de 6 xilosidase purificada e produção de derivados ativos estabilizados. 2012. 212 p. Tese (Doutorado em Bioquímica) - Departamento de Bioquímica e Imunologia da Faculdade de Medicina de Ribeirão Preto, Universidade de São Paulo, Ribeirão Preto, 2012.

BENASSI, V. M. PASIN, T. M.; FACCHINI, F. D. A.; JORGE, J. A., POLIZELI, M. L. T. M. A novel glucoamylase activated by manganese and calcium produced in submerged fermentation by Aspergillus phoenicis, J. Basic Microbiol. 54, 333ї 339. 2014.

BORZANI, W.; SCHMIDELL, W.; LIMA, U. de A.; Aquarone, E. Biotecnologia industrial., v. 1. $1^{\text {a }}$ ed., São Paulo: Editora Blucher, 2001.

CARLSON, M. Regulation of sugar utilization in Saccharomyces species. The Journal of Bacteriology, Washington, v. 169, n. 11, p. 4873-4877, 1987.

CARRASCO, M.; BAEZA, M. Purification and characterization of a novel Ŭglucosidase from an Antarctic yeast Dioszegia fristingensis isolate. Amylase, v. 1, p. 50 ï 58, 2017.

CAVALCANTI, M. A. Q.; OLIVEIRA, L. G.; FERNANDES, M. J., LIMA, D. M. Fungos filamentosos isolados do solo em municípios na região Xingó, Brasil. Acta botânica brasileira, v. 20, n. 4, p. 831 ï 837, 2006.

COELHO, M. A. Z.; SALGADO, A. M., RIBEIRO, B. D. Tecnologia Enzimática. FAPERJ; Petrópolis, RJ: EPUB, 2008.

CORRÊA, F. A. S. F. Criação em laboratório de Condylorrhiza vestigialis (Guenée, 1854) (Lepidoptera: crambidae) com diferentes dietas artificiais. 2006. 95 f. Dissertação (Mestrado) - Universidade Federal do Paraná, Curitiba, PR, 2006.

DOMSCH, K. H.; GAMS, W.; ANDERSON, T. H. Compendium of soil fungi. $2^{\mathrm{a}}$ ed., Eching: IHW-Verlag, 2007.

DUTTON, M; EVANS, C. Oxalate production by fungi: its role in pathogenicity and ecology in the soil environment. Canadian Journal of Microbiology, v. 42, n. 9, p. 881895, feb. 2011.

EMERSON, R. An experimental study of the life cycles and taxonomy of Allomyces. Lloydia, v. 4, p. 77-144, 1941.

EZEJI T. C.; WOLF A.; BAHL H. Isolation, characterization, and identification of Geobacillus thermodenitrificans HRO10, an alpha-amylase and alpha-glucosidase producing thermophile. Can. J. Microbiol, v. 51, n. 8, p.685-693, jul. 2005.

FACCHINI, F. D. A. Bioprospecção e produção de enzimas fibrolíticas por Aspergillus japonicus com potencial para aplicação em nutrição de ruminantes. 2010. 153 p. Dissertação (Mestrado em bioquímica) - Faculdade de Medicina de Ribeirão Preto, Universidade de São Paulo,
Ribeirão Preto, SP, 2010.

FREITAS, L. S.; MARTINS, E. S.; FERREIRA, O. E. Produção e caracterização parcial de Ŭ amylase de Syncephalastrum racemosum. Revista Brasileira de Biociências, v. 12, n. 4, p.226- 232, oct/dec. 2014. Available at: http://www.ufrgs.br/seerbio/ojs/index.php/rbb/article/vi ewFile/3120/1258>. Accessed on june $06^{\text {th }}, 2020$.

GOMES, D. N. F. Diversidade e potencial biotecnológico de fungos filamentosos isolados do manguezal Barra das Jangadas, Jaboatão dos Guarapes. 2007. 94 f. Tese (Doutorado) ï Programa de pós-graduação em biologia de fungos, Universidade de Pernambuco. Recife, PE. 2007.

GOMES, E.; GUEZ, M. A. U.; MARTIN, N.; SILVA, R. Enzimas termoestáveis: fontes, produção e aplicação industrial. Química Nova, v. 30, n. 1, p. 136-145, jan./fev. 2007. Available at: <https://www.scielo.br/pdf/qn/v30n1/24.pdf >. Accessed on june $06^{\text {th }}, 2020$.

GONÇALVES, G. L. Produção de amilases de Rhizopus microsporus var oligosporus e hidrólise enzimática do bagaço de mandioca visando produção de etanol por Saccharomyces cerevisiae. 2016. 66 f. Dissertação (Mestrado em Ciências Biologicas) - Universidade Estadual Paulista Júlio de Mesquita Filho. Rio Claro, SP, 2016.

GRIEBELER, N. E.; BORTOLI, V.; ASTOLFI, A. L.; DARONCH, N. A.; SCHUMANN, A. C.; SALAZAR, L. N.; CANSIAN, R. L.; BACKES, G. T.; ZENI, J. Seleção de fungos filamentosos produtores de amilases, proteases, celulases e pectinases. Ver. Acad. Ciênc. Anim., v.13, p. 13 ï 22, 2015. Available at: < https://periodicos.pucpr.br/index.php/cienciaanimal/arti cle/view/11174/10511>. Accessed on june $06^{\text {th }}, 2020$.

KHANNA, P.; SUNDARI, S. S.; KUMAR, N. J. Production, isolation and partial purification of xylanase from Aspergillus sp. World J. Microbiol. Biotechnol., v. 11, n.2, p. 242-243, mar. 1995.

LACAZ, C. S.; PORTO, E.; MARTINS, J. E. C. Micologia Médica. $8^{\text {a }}$ ed. São Paulo: Sarvier, p.695, 1991.

LEADLAY, P. F. An Introduction to Enzyme Chemistry. Cambridge: The Royal Society of Chemistry, 1993, 82 p.

LIMA, M. S. et al. Potencial de fungos filamentosos na produção de enzimas utilizando diferentes fontes de carbono. Revista brasileira de agrotecnologia, v. 5, n. 1, p. 49 ï 53, 2015.

MICHELIN, M. et al. Purification and characterization of a thermostable a-amylase produced by the fungus Paecilomyces variotii. Carbohydrate Research, v. 345, n. 16, p. 2348 ï 2353, 2010.

MICHELIN, M. Potencial dos fungos Aspergillus terrícola e Aspergillus ochraceus no desenvolvimento de bioprocessos e propriedades das enzimas xilanolíticas. 2009. 236 f. Tese (Doutorado em Ciências ï Biologia Comparada) ï Faculdade de Filosofia, Ciências e Letras de Ribeirão Preto, Universidade de São Paulo, Ribeirão Preto, 2009.

MILLER, G. L. Use of dinitrosalicylic acid reagent for determination of reducing sugar. Analytical Chemistry, Washington, v. 31, n. 3, p. 426-428, mar. 1959. 
MUSSATO, S. I.; FERNANDES, M.; MILAGRES, A. M. F. Enzimas: Poderosa ferramenta na indústria. Ciência Hoje, vol. 41, n. 242, p. 28- 33, 2007.

MING CHU, I.; LEE, C.; LI, T. S. Production and degradation of alkaline protease in batch cultures of Bacillus subtilis ATCC 14416. Enzyme Microbiology Technology, v. 14, n. 6, p. 755-761, 1992.

NGUYEN, Q. D. et al. Purification and characterisation of amylolytic enzymes from thermophilic fungus Thermomyces lanuginosus strain ATCC 34626. Enzyme Microbiology Technology, v. 31, n. 3, p. 345-352, 2002.

NWAGU, T. N.; OKOLO, B. N. Extracellular amylase production of a thermotolerant Fusarium sp isolated from Eastern Nigerian soil. Brazilian Archives of Biology and Technology, Curitiba, v. 54, n. 4, p. 649 ï 658, Jul/Ago. 2011a.

NWAGU, T. N.; OKOLO, B. N. Growth Profile and Amylase Hydrolytic Activity of a Thermophilic Fungi Aspergillus fumigates Isolated from Soil. Asian Journal of biotechnology, Malaysia, v. 3, n. 1, 46 ï 57, jan. $2011 \mathrm{~b}$.

OLIVEIRA, A. C. D.; WATANABE, F. M. F.; RODRIGUES, M. L. F. Comparação entre fermentação no estado sólido e fermentação submersa para produção de Ǔ-amilases por Penicillium sp. e caracterização da enzima. Revista Eletrônica Biociências, Biotecnologia e Saúde. n. 1, p. 1-12, 2011.

OLIVEIRA, C.; MULLER, F.; SEGATO, M. Departamento de Engenharia Química e de Alimentos. Aplicações de enzimas em produtos de limpeza. Florianópolis: Trabalhos de graduação do grupo de processos biotecnológicos da UFSC, 2004.

OLIVEIRA, S. D. J. Produção de enzimas por fungos em fermentação semi-sólida utilizando bagaço de coco e pedúnculo de caju como substratos. 2014. $103 \mathrm{f}$ Dissertação (Mestrado em engenharia química) ï Departamento de engenharia química, Universidade Federal do Rio Grande do Norte. Natal, 2014.

PANDEY, A.; WEBB, C.; SOCCOL, C.R.; LARROCHE, C. Enzyme Technology. $1^{\text {a }}$ ed. New Delhi: Asiatech Publishers, Inc., p. 760, 2005.

PANDEY, A.; SELVAKUMAR, P.; SOCCOL C. R.; NIGAM, P. Solid-State Fermentation for the production of Industrial Enzymes. Current Science, v. 77, n. 1, p. 149162, JUL. 1999.

PANDEY, R. K.; TEWARI, L. Microbial enzymes involved in starch processing industries. Scholarly Journal of Biological Science, v. 4, n. 1, p. 1 ï 3, Jan. 2015.

PARIS, L. D.; SCHEUFELE, F. B.; TEIXEIRA JUNIOR, A.; GUERREIRO, T. L.; HASAN, S. D. M.. Produção de complexos enzimáticos por $A$. Níger a partir da soja por fermentação em estado sólido. Acta Scientiarum, Maringá, v. 34, n. 2, p. 193 ï 200, apr ï june 2012.

PASIN, T. M.; BENASSI, V. M.; MOREIRA, E. A.; JORGE, J. A.; POLIZELI, M. L. T. M. Prospecting filamentous fungi for amylase production: standardization of Aspergillus japonicus culture conditions, Br. Biotechnol. J. v. 4, n. 4, p. 482ï 498, apr. 2014.

PASIN, T. M. Prospecção, purificação e propriedades funcionais de uma glucoamilase de Aspergillus japonicus: Aplicação do extrato enzimático em reciclagem de papel. Dissertação (Mestrado em Ciências) - Faculdade de Medicina de Ribeirão Preto, Universidade de São Paulo, Ribeirão Preto, 2015.
PASIN, T. M.; BENASSI, V. M.; HEINEN, P. R.; DAMASIO, A. R. L.; CEREIA, M.; JORGE, J. A.; POLIZELI, M. L. T. M. Purification and functional properties of a novel glucoamylase activated by manganese and lead produced by Aspergillus japonicus. Int J Biol Macromol. v. 102, p. 779-788, 2017.

PASIN, T. M.; MOREIRA, E. A.; LUCAS, R. C.; BENASSI, V. M.; ZIOTTI, L. S.; CEREIA, M.; POLIZELI, M. L. T. M. Novel amylase-producing fungus hydrolyzing wheat and brewing residues, Aspergillus carbonarius, discovered in tropical forest remnant. Folia Microbiol (Praha). v. 65, n. 1, p. 173-184, jun 2019.

PEIXOTO, S. C.; JORGE, J. A.; TERENZI, H. F.; POLIZELI, M. L. T. M. Rhizopus microsporus var. rhizopodiformis: a thermotolerant fungus with potential for production of thermostable amylases. Int. Microbiol., v. 6, n. 4, p. 269273, dec. 2003.

PELCZAR, M. J.; CHAN, E. C. S.; KRIEG, N. R. Microbiologia: Conceitos e Aplicações, vol. 1, $2^{\mathrm{a}}$ ed., São Paulo: MAKRON Books, 1997.

PEREIRA, C. R. Produção de amilases por Aspergillus niger: potencial de aplicação na hidrólise do amido granular da batata-doce. 2015. 82 p. Dissertação (Mestrado em bioenergia) ï Programa de pós-graduação em bioenergia, Universidade Estadual do Centro-oeste. Guarapuava, 2015.

PIRES, T. C. R.; VEIGA, E. M.; FINARDI-FILHO, F.; ENZIMAS AMILOLÍTICAS DE MANDIOQUINHASALSA (Arracacia xanthorrhiza Bancroft.). Ciência e tecnologia de alimentos, Campinas, v. 22, n. 3, p. 278 ï 284, sep. ï dec. 2002

POLITZER, K.; BON, E. P. S. Enzimas Industriais e Especiais. Centro de Gestão e Estudos Estratégicos, Ciência, Tecnologia e Inovação, IQ/UFRJ, Rio de janeiro, may 2006.

Report overview, In: Global Markets for Enzymes in Industrial Applications. BCC RESEARCH, BIO030J, 2017, 1 ï 5.

RIZZATTI, A. C. S. et al. Purification and properties of a thermostable extracellular ǓD-xylosidase produced by thermotolerant Aspergillus phoenicis. J. Ind. Microbiol. Biotechnol., v. 26, n. 3, p. 156-160, Mar. 2001.

ROSADO, J. G. de J. Seleção e identificação de cepas bacterianas produtoras de amilases isoladas da microbiota associada a resíduos agrícolas de cacau e dendê. 2013. 77 f. Dissertação (Mestrado em biotecnologia) ï Instituto de ciências da saúde, Universidade Federal da Bahia, Salvador, 2013.

SALES, M. R.; MOURA, R. B.; PORTO, T. S.; MACEDO, G. R.; PORTO, A. L. F. Variáveis que influenciam a produção de celulases e xilanase por espécies de Aspergillus. Pesq. agropec. bras., Brasília, v. 45, n. 11, p. 1290-1296, nov. 2010.

SANTOS, J. A. F. Avaliação dos resíduos dos processamentos de suco de laranja e de cerveja para obtenção de ácido cítrico por fermentação em estado sólido. 2008. 102 f. Dissertação (Mestrado em Biotecnologia Industrial) Escola de Engenharia de Lorena Universidade de São Paulo. Lorena/SP, 2008.

SILVA, T. M. Produção e determinação das propriedades funcionais das amilases de Aspergillus niveus. 2009. 171 p. Tese (Doutorado em ciências) - Faculdade de Filosofia, Ciências e Letras de Ribeirão Preto, Universidade de São Paulo. Ribeirão Preto, 2009; 
SILVA, W. B.; PERALTA, R. M. Caracterização bioquímica de uma enzima extracelular de um fungo termotolerante. Biological and Health Sciences, v. 6, n. 1, p. 7-19, 2000

SPIER, M. R. Produção de enzimas amilolíticas fúngicas Ǔ amilase e amiloglucosidase por fermentação no estado sólido. 2005. 178 p. Dissertação (Mestrado em Tecnologia de Alimentos), Universidade Federal do Paraná, Curitiba, 2005.

VERON, N. W. Mutagênese clássica e melhoramento do perfil de assimilação de nitrogênio para a produção de amilase por Talaromyces trachyspermus. 2016. 113 p.
Dissertação (Mestrado em bicombustíveis) ï Programa de Pós-graduação em bicombustíveis, Universidade Federal dos Vales do Jequitinhonha e Mucuri. Diamantina, 2016.

WANDERLEY, M. D.; NEVES, E.; ANDRADE, C. J. de. Aspectos da produção industrial de enzimas. Citino, v. 1, n. 1, p. 44-50, 2011.

WISEMAN, A.; WOODWARD, J. Industrial yeast Invertase stabilization. Process Biochem., v. 10, p. 24-30, 1975. 